\title{
Overview of the Federal Prohibition on Market Abuse in the United States of America*
}

\author{
Howard Chitimira \\ LLB LLM LLD \\ Lecturer, Faculty of Law, North-West University \\ E-mail:Howard.Chitimira@nwu.ac.za
}

Doi:10.5901/mjss.2014.v5n7p119

\begin{abstract}
The United States of America (the US) has a relatively broad and adequate market abuse prohibition in place at a federal level. For instance, insider trading, market manipulation and other related illicit activities such as tipping and short selling are regulated at a federal level in the US. This approach has to date relatively culminated in greater deterrence, compliance and curbing of market abuse practices across the US financial markets. It is against this background that this article provides a brief overview analysis of the regulation and enforcement of the market abuse prohibition in the US at a federal level. This is done by, first, discussing the development, prohibition and the available penalties and remedies for insider trading. Secondly, a similar analysis will be done in respect of market manipulation. Moreover and where necessary, relevant federal provisions and cases from the US will be contrasted with similar provisions and cases in South Africa in order to recommend, where appropriate, possible anti-market abuse measures that could be employed to enhance the combating of market abuse practices in South Africa.
\end{abstract}

Keywords: market abuse, insider trading, remedies, penalties, market manipulation.

\section{Introduction}

The United States of America (the US) has a relatively broad and adequate market abuse prohibition in place at a federal level. For instance, insider trading, market manipulation and other related illicit activities such as tipping and short selling ${ }^{1}$ are regulated at a federal level in the US. This approach has to date relatively culminated in greater deterrence, compliance and curbing of market abuse practices across the US financial markets. ${ }^{2}$ It is against this background that this article provides a brief overview analysis of the regulation and enforcement of the market abuse ${ }^{3}$ prohibition in the US at a federal level. ${ }^{4}$ This is done by, first, discussing the development, prohibition and the available penalties and remedies for insider trading. Secondly, a similar analysis will be done in respect of market manipulation. Moreover and where necessary, relevant federal provisions and cases from the US will be contrasted with similar provisions ${ }^{5}$ and cases in South Africa in order to recommend, where appropriate, possible anti-market abuse measures that could be employed to enhance the combating of market abuse practices in South Africa. ${ }^{6}$

\footnotetext{
*Influenced in part, by Chitimira A Comparative Analysis of the Enforcement of Market Abuse Provisions (LLD Thesis 2012 NMMU) 210-257. Accordingly, I wish to thank Professor Lawack.

${ }^{1}$ Short selling has been regulated at a federal level in the US as early as 1938 through the price test prohibition (uptick rule). This prohibition was formerly referred to as Rule 10a-1 of the Securities Exchange Act of 193415 USC 78i(a)(2)-(5) (2006) as amended by PL-111-257. See further Rule 10b-21 (a naked short selling anti-fraud Rule) which is also a final Rule under the aforesaid Act.

2 Steinberg "Insider Trading Regulation-A Comparative Perspective" 2003 The International Lawyer 153 169-171. Also see Bhattacharya \& Daouk "The World Price of Insider Trading" 2002 Journal of Finance 75 75-108; Lyon \& Du Plessis The Law of Insider Trading in Australia (2005) 159-168 \& Avgouleas The Mechanics and Regulation of Market Abuse: A legal and Economic Analysis (2005) 75-502, for further analysis on the regulation and enforcement of the market abuse ban in other countries.

${ }^{3}$ Includes both insider trading and market manipulation in this article.

4 Steinberg 2003 The International Lawyer 169.

${ }^{5}$ See ss 78; 80; 81 \& 82 of the Financial Markets Act 19 of 2012, hereinafter referred to as the Financial Markets Act.

6 See related remarks by Van Deventer "Anti-Market Abuse Legislation in South Africa" (10-06-2008) 1-5 <http://www.fsb.co.za/public/marketabuse/FSBReport.pdf> (accessed 05-05-2013) \& see further Myburgh \& Davis "The Impact of South Africa's Insider Trading Regime: A Report for the Financial Services Board" (25-03-2004) 8-33 <http://www.genesis-analytics.com/public/FSBReport.pdfs (accessed 09-022013). Also see Chanetsa "Insider Trading is Notoriously Hard to Prosecute" Business Report 26 April 2004; Pretorius and Another v Natal South Sea Investment Trust 19653 SA 410 (W), were the courts failed to convict the suspected insider trading offenders; Chitimira A Comparative Analysis of the Enforcement of Market Abuse Provisions (2012) 210-257; Botha "Control of Insider Trading in South Africa: A Comparative Analysis" 1991 SA Merc LJ 11 18; Botha "Increased Maximum Fine for Insider Trading: A Realistic and Effective Deterrent?" 1990 SALJ 504-508; Chitimira The Regulation of Insider Trading in South Africa: A Roadmap for an Effective, Competitive and Adequate Regulatory Statutory Framework (2008) LLM dissertation, University of Fort Hare, 41-72; Osode "The new South African Insider Trading Act: Sound law reform or legislative overkill?" 2000 Journal of African Law 239 239-263; Jooste
} 


\section{Historic Overview of the Federal Prohibition on Market Abuse}

\subsection{Overview of the Development of the Insider Trading Prohibition}

The regulation of insider trading at a federal level in the US was introduced by the Securities Exchange Act of 1934. ${ }^{7}$ Before the Securities Exchange Act, cases dealing with insider trading were reportedly inconsistently decided on the basis of existing common law. ${ }^{8}$ The Securities Exchange Act discouraged insider trading and other related practices in the US both directly ${ }^{9}$ and indirectly. ${ }^{10}$ Nonetheless, its direct prohibition on insider trading applied only to directors or officers (primary insiders) of a company who held more than a $10 \%$ stake in the company. ${ }^{11}$ In other words, this direct prohibition on insider trading did not expressly apply to other persons like tippees. Moreover, the Securities Exchange Act's indirect prohibition on insider trading was generally employed as an anti-fraud provision which prohibited insiders from defrauding other innocent investors by trading in their own company's stock while in possession of advance knowledge of a forthcoming earnings disclosure. ${ }^{12}$ Notably, the Securities Exchange Act imposed a mandatory disclosure requirement on all insiders. ${ }^{13}$ They had to file with the SEC any requested statements and/or transactions, including those that could amount to insider trading, within ten days after they were concluded.

The initial insider trading provisions of the Securities Exchange Act were, however, flawed in some respects. For example, they did not give sufficient authority to the SEC ${ }^{14}$ to enforce and recover profits that were illegally obtained by those who practised insider trading. ${ }^{15}$ This function was merely left to a company's own managers, directors and shareholders. ${ }^{16}$ Additionally, the SEC introduced other anti-fraud provisions such as Rule $10 \mathrm{~b}-5^{17}$ but they nonetheless remained deficient. Neither section 10(b) nor Rule 10b-5 expressly prohibited illicit insider trading by insiders or other unscrupulous persons. The successful prosecution or settlement of insider trading cases was contingent upon the interpretation of the courts. ${ }^{18} \mathrm{It}$ is clear that non-disclosure by an insider of material facts that were not known to the other party during the negotiations could probably amount to other market abuse practices like market manipulation. In 2000 the SEC adopted Rule $10 \mathrm{~b} 5-1^{19}$ in an attempt to define insider trading and provide defences to any person charged with insider trading if such person purchases or sells securities before acquiring material non-public information. ${ }^{20}$ The SEC further adopted Rule 10b5-2 $2^{21}$ to provide clarity on when a breach of a fiduciary duty or otherwise gives rise to liability under the misappropriation theory of insider trading in order to increase the consistent enforcement of the federal insider trading prohibition. ${ }^{22}$ In the same light, the SEC adopted Rule 100 and Regulation Fair Disclosure ${ }^{23}$ in a bid to discourage companies from selectively disclosing material non-public information to market professionals and favoured shareholders in another attempt to combat insider trading.

"A critique of the insider trading provisions of the 2004 Securities Services Act" 2006 SALJ 437 441-460; Van Deventer "New watchdog for insider trading" 1999 FSB Bulletin 23 \& Luiz "Insider Trading Regulation - If at First You Don't Succeed..." 1999 SA Merc LJ 136 136-151.

7 Public Law 73-291, 48 Stat 88115 USC 78a-78ll as amended (hereinafter referred to as the Securities Exchange Act). See $s$ 16(a) \& (b) as well as $s$ 10(b); also see Hazen Federal Securities Law (2003) 1-4.

${ }^{8}$ Godwin v Agassiz (1933) 186 NE 659 (Mass), where the plaintiff who had ignorantly sold his own shares to his detriment after having read a newspaper report stating that the company had stopped operating as a result of insider trading was denied relief by the Supreme Court of Massachusetts.

${ }^{9} S 16(b)$ prohibited short-swing profits (profits obtained in less than 6 months) by corporate insiders in the corporation's stock except when it was in the best interests of that corporation or its shareholders.

${ }_{10} \mathrm{~S} 10$ (b) prohibited any person to use or to employ in the purchase or sale of any securities registered on a securities exchange or any unregistered securities, a deceptive device for the purpose of contravening any rules and regulations of the United States Securities and Exchange Commission (the $S E C)$.

${ }^{11} S 16(b)$ read with subsection (a).

12 S 10(b) read with subsection (a). Also see generally related remarks in SEC v Lipson (2001) No 97-CV-2661 129F Supp.2d 1148.

${ }_{13} S$ 16(a).

14 This body was established in 1934 as an independent board to enforce the federal securities laws so as to combat market practices like insider trading in the US.

${ }^{15} S 16(a) \&(b)$.

${ }^{16}$ Steinberg 2003 The International Lawyer 169-171.

1717 CFR, s 240.10b-5 (2007); Rule 10b-5 can be downloaded at <http://www.sec.gov> (accessed 01-02-2014).

${ }^{18}$ As demonstrated in Cady, Roberts and Company [1961-1964 Transfer Binder] CCH Fed Sec L Rep 76. 803 81. 016 \& Chiarella v United States (1980) 445 US 222-230.

1917 CFR, 240.10b5-1; Rule 10b5-1 can be downloaded at <http://www.sec.gov> (accessed 01-02-2014).

${ }^{20}$ Horwich "The Origin, Application, Validity and Potential Misuse of Rule 10b5-1" 2007 The Bus. Lawyer 913 922-923.

2117 CFR, 240.10b5-2; Rule 10b5-2 can be downloaded at <http://www.sec.gor> (accessed 01-02-2014).

22 Pearson "When Hedge Funds Betray A Creditor Committee's Fiduciary Role: New Twists on Insider Trading in the International Financial Markets" 2009 Review of Banking \& Financial Law 165204.

${ }^{23}$ Securities Exchange Act Release Number 43154 [2000 Transfer Binder] Fed Sec L Rep CCH 86 319. These rules and regulations can be downloaded at <http://www.sec.gov> (accessed 01-02-2014); also see <http://www.sec.gov/rules/final/33-7881.htm\#P22_3882> (accessed 01-02-2014); also see related analysis by Palmiter Securities Regulation: Examples and Explanations (2005) 371 \& Morrison \& Foerster “Insider Trading" 2010 Year End Review 1 1-6. 
The Securities Exchange Act was amended and introduced provisions that granted the SEC the authority to make rules that are appropriate and necessary 24 for the enforcement of the securities laws. ${ }^{25}$ Therefore, the SEC adopted Rule $14 \mathrm{e}-3^{26}$ which applied only in tender offer situations. Rule $14 \mathrm{e}-3$ prohibited "any person who has obtained directly or indirectly, material confidential information" regarding a tender offer from the offeror (bidder), target company or an intermediary, to trade or tip another person to trade in that offer before making an adequate public disclosure of such information. Furthermore, a tippee who knew or should have known that such information had come from an insider was prohibited from trading with it until an adequate public disclosure was made. Rule 14e-3 applied to all persons (even juristic persons) but nevertheless it was not easily enforced in practice. Besides being a basis for some of the SEC's enforcement actions, Rule $14 \mathrm{e}-3$ has been very difficult to enforce and in some instances it is confusingly interpreted to create an implied private action against the offenders. ${ }^{27}$

Various shortcomings of the Securities Exchange Act led the Congress to enact the Insider Trading Sanctions Act of $1984^{28}$ at the request of the SEC. This Act for the first time empowered the SEC to bring a civil action in the federal districts courts against persons who engage in insider trading activities. ${ }^{29}$ Therefore, the SEC could impose civil penalties on anyone who practised insider trading through tipping or other related practices to pay an amount of up to three times the profit made or loss avoided for the benefit of all the persons who were prejudiced by it. The Insider Trading Sanctions Act further empowered the courts to impose a criminal penalty on any person who violated the insider trading provisions ${ }^{30}$ In spite of these developments, the Insider Trading Sanctions Act still failed to provide a lasting solution to the enforcement problems in the US. It did not expressly define insider trading and its provisions applied only to a few persons (primary insiders); other persons like "controlling persons" 31 were not specifically prohibited from committing insider trading offences. ${ }^{32}$

In a bid to improve the regulation of insider trading, the Congress passed the Insider Trading and Securities Fraud Enforcement Act of 1988. ${ }^{33}$ This Act stipulated that public companies, broker-dealers and investment advisors should adopt appropriate policies to monitor and prohibit their employees from practising insider trading. ${ }^{34}$ Moreover, the Securities Fraud Enforcement Act modified the wording of section 21A to make it clear that tippers could be liable for civil penalties when their tip resulted in insider trading, even if they are not technically aiders and abettors. ${ }^{35}$ The Securities Fraud Enforcement Act broadened the treble penalty for insider trading ${ }^{36}$ and further imposed liability on "controlling persons" for insider trading activities of their employees. ${ }^{37}$ This Act also permitted the SEC to pay bounties to informants of up to $10 \%$ of the civil penalties recovered in order to promote and enhance the enforcement of insider trading in the US. ${ }^{38}$ These bounties were not paid to members, officers or employees of federal regulatory agencies, Department of Justice and self-regulatory organisations. ${ }^{39}$ The Securities Fraud Enforcement Act further empowered the SEC to investigate upon the request of similar regulatory bodies elsewhere any insider trading practices, regardless of whether such practices violated the SEC's federal insider trading laws. ${ }^{40}$ In spite of the notable improvements brought by the Securities Fraud Enforcement Act, some persons were still able to contravene its insider trading provisions. For example,

\footnotetext{
${ }^{24} S 23(a)(1)$

${ }^{25} S$ 14(e).

2617 CFR, s 240.14e-3 (2007); Rule 14e-3 can be downloaded at <http://www.sec.gov> (accessed 01-02-2014). See further Arshadi \& Eyssell The Law and Finance of Corporate Insider Trading: Theory and Evidence (1993) 46; Gaillard (ed) Insider Trading: The Laws of Europe, the United States and Japan (1992) 296; Palmiter Securities Regulation 368; Ryan "Rule14e-3's Disclose or Abstain Rule and Its Validity under Section 14(e)" 1991 U. Cin. Law Review 449 453-454 \& Pearson 2009 Review of Banking \& Financial Law 191-204.

${ }^{27}$ Palmiter Securities Regulation 368. Also see United States v O'Hagan (1997) 117 (SCt) 2199; United States v Chestman (1991) 947 F2d 551 (2d Cir).

${ }^{28}$ Public Law 98-376, 98 Stat.1264 (1984), hereinafter referred to as the Insider Trading Sanctions Act.

${ }^{29}$ Gilson \& Kraakman "The Mechanisms of Market Efficiency" 1984 VA.L.REV 549 \& Friedman "The Insider Trading and Securities Fraud Enforcement Act of 1988" 1990 North Carolina Law Review 465 466-494.

${ }^{30} \mathrm{~S} 21 \mathrm{~A}$.

${ }^{31} \mathrm{~A}$ "controlling person" includes not only employers but also any person with the power to influence or control the direction or the management policies or activities of another person. Gaillard Insider Trading: The Laws of Europe, the United States and Japan 308.

${ }_{32}$ Pearson 2009 Review of Banking \& Financial Law 194.

${ }_{33}$ Public Law 100-704, 102 Stat. 4677, hereinafter referred to as the Securities Fraud Enforcement Act.

${ }^{34}$ Arshadi \& Eyssell The Law and Finance of Corporate Insider Trading 51 \& Pearson 2009 Review of Banking \& Financial Law 195.

${ }^{35} S 21 A(d)$.

${ }^{36}$ Pearson 2009 Review of Banking \& Financial Law 195.

${ }^{37} \mathrm{~S} 21 \mathrm{~A}$ as amended.

${ }^{38}$ Kaswell "An Insider's View of the Insider Trading and Securities Fraud Enforcement Act" 1989 Bus.Law $145152-164$ \& Fisher, Harshman, Gillespie, Ordower, Ware \& Yeager "Privatizing Regulation: Whistle-blowing and Bounty Hunting in the Financial Services Industries" 2000 Dick.J. Int'L. L 117 135136 \& Pearson 2009 Review of Banking \& Financial Law 195

39 Friedman 1990 North Carolina Law Review 466-494.

${ }^{40}$ See s 6(b)(2) of the Securities Fraud Enforcement Act, which amended s 21(a)(2) of the Securities Exchange Act; also see Pearson 2009 Review of Banking \& Financial Law 195.
} 
as a result of poor auditing and insider trading activities on the part of Enron's directors, its net income was reduced by $\$ 600$ million and its debt increased to about $\$ 628$ million. ${ }^{41}$

In 2000, the Commodities Futures Modernization Act ${ }^{42}$ was enacted to inter alia repeal the ban on single-stock futures, enhance the regulation futures exchanges and empower both the Commodity Futures Trading Commission (the CFTC) and the SEC to share the responsibility of regulating insider trading in the single-stock futures markets. ${ }^{43}$ This Act, unlike the Commodity Exchange Act of 1936,44 further enabled the CFTC to prohibit insider trading by discouraging market regulators' employees and other professionals like brokers from trading ahead of a client or other investors while in possession of non-public material information. ${ }^{45}$ The aforementioned insider trading prohibition was, however, not extended to other persons who are not market professionals or employees per se.46

In 2002 the Congress enacted the Public Company Accounting Reform and Investor Protection Act of $2002^{47}$ in response to several landmark corporate scandals like World Com and Enron. ${ }^{48}$ This Act brought a more rigorous regulatory and enforcement structure for accounting companies and professionals to combat corporate fraud, insider trading and other market abuse practices. ${ }^{49}$ For example, in order to prevent insider trading, the Sarbanes-Oxley Act prohibits employees (primary insiders) from trading in their company's stock relating to its pension plan funds during closed periods. ${ }^{50}$

In the wake of the 2007-2008 global financial crisis, the Congress recently enacted the Dodd-Frank Wall Street Reform and Consumer Protection Act of $2010^{51}$ to inter alia enhance and broaden the SEC's ability to enforce insider trading and other securities laws. ${ }^{52}$ For instance, this Act now allows the SEC and/or the CFTC to institute appropriate proceedings against any employee or agent of an agency or department of the federal government who purchases or sells a commodity while in possession of non-public material information which relates to that commodity. ${ }^{53}$ In relation to this, the Dodd-Frank Act empowers the SEC to enforce the federal anti-fraud securities and insider trading prohibition extra-territorially. ${ }^{54}$ The Dodd-Frank Act now provides incentives of up to $30 \%$ and immunity to whistleblowers who report insider trading and related violations to the SEC or the CFTC. ${ }^{5}$

In contrast to the early developments of the regulation and enforcement of the insider trading ban in the US, 56 the legislature in South Africa only introduced a prohibition on insider trading in $1973 .{ }^{57}$ Nonetheless, like the position in the US, ${ }^{58}$ the South African regulatory framework also prohibits any person (including juristic persons) from practising insider trading and related activities like tipping. ${ }^{59}$ For instance, the Financial Markets Act merely enumerates and prohibits four types of practices, namely, (a) dealing (directly or indirectly) in securities listed on a regulated market by an insider who knows that he has inside information which relates to such securities for his own personal benefit; 60 (b) dealing (directly or indirectly) in securities listed on a regulated market by an insider who knows that he has inside information which

\footnotetext{
${ }^{41}$ Palmiter Securities Regulation 24.

42 Public Law 106-554, 114 Stat.2763A-365, hereinafter referred to as the Commodities Futures Modernization Act.

${ }^{43}$ Knepper "Examining the Merits of Dual Regulation for Single-Stock Futures: How the Divergent Insider Trading Regimes for Federal Futures and Securities Markets Demonstrate the Necessity for (and Virtual Inevitability of) Dual CFTC-SEC Regulation for Single-Stock Futures" 2004 Pierce Law Review 33 34-45.

447 USC 1 et seq. (1994). Hereinafter referred to as the Commodity Exchange Act and it came into effect on 15 June 1936.

${ }^{45}$ See the CFTC Regulation 1.59, 17 CFR, 1.59 (2004); also see Markham "Front-Running'-Insider Trading under the Commodity Exchange Act" 1988 Cath.U.Review 69 94; 110 \& Knepper 2004 Pierce Law Review 40--45.

${ }^{46}$ Knepper 2004 Pierce Law Review 42-45; also see the CFTC \& the SEC "A Joint Report of the SEC and the CFTC on Harmonization of Regulation" Report 16 October 20091 6-7; 59-61.

${ }_{47}$ Public Law 107-204, 116 Stat 745 (as codified in scattered sections of 15; 28 USC), hereinafter referred to as the Sarbanes-Oxley Act. See further Palmiter Securities Regulation 23.

${ }^{48}$ Avgouleas The Mechanics and Regulation of Market Abuse 449.

${ }^{49}$ This heading discusses mainly the US's federal statutes on insider trading. Other statutes that specifically regulate and prohibit fraud such as the Racketeer Influenced and Corrupt Organization Act of 1970 (RICO) will not be discussed for purposes of this thesis because it is limited only to the enforcement of the insider trading and market manipulation prohibition.

${ }^{50} \mathrm{~S} 306(\mathrm{a})$

${ }^{51}$ Public Law 111-203, 124 Stat.1376 (codified at 12 USC, s 5301 et seq.), hereinafter referred to as the Dodd-Frank Act.

52 Morrison \& Foerster 2010 Year End Review 11-13.

${ }^{53} \mathrm{~S} 746$ of the Dodd-Frank Act.

54 S 929P(b) read with (c) of the Dodd-Frank Act; also see Morrison \& Foerster 2010 Year End Review 14-15.

${ }^{55}$ See s 922 of the Dodd-Frank Act which enacted s 21F to repeal and replace s 21A(e) of the Securities Exchange Act; see further Morrison \& Foerster 2010 Year End Review 12-14.

${ }^{56}$ See earlier remarks above.

${ }^{57}$ S 224 \& ss 229 to 233 of the now repealed Companies Act 61 of 1973, hereinafter referred to as the Companies Act. See further the Explanatory Memorandum to the Objects of the Companies Second Amendment Bill of 1990 B 119-90 (GA); Botha 1991 SA Merc LJ 4.

${ }_{58}$ See earlier remarks above.

${ }^{59}$ See ss 78 \& 82 read with ss 77 \& 79 of the Financial Markets Act.

$60 S 78(1)(a)$ read with subsection (3)(a) \& $s 82$.
} 
relates to such securities for the benefit of another person; ${ }^{61}$ (c) improper disclosure of inside information to another person by an insider who knows that he has such information; 62 and (d) the encouraging or discouraging of another person by an insider, to deal in securities listed on a regulated market. ${ }^{63}$ Despite these similarities, there is no express provision that prohibits dealing in securities on unregulated over the counter markets through agents in South Africa. ${ }^{64}$ Over and above, unlike the situation in the US, ${ }^{65}$ the Financial Markets Act does not expressly prohibit other related illicit activities such as naked short selling. ${ }^{66}$

\subsection{Available Penalties for Insider Trading}

The US's enforcement framework uses civil, criminal and administrative penalties to discourage insider trading. This can be traced back to the Securities Act of $1933^{67}$ which provided that any person who contravened its provisions was criminally liable for a fine of $\$ 10000$, or imprisonment for a period not exceeding five years, or both such fine and imprisonment. ${ }^{68}$ Moreover, the Securities Exchange Act allows the SEC to impose any other appropriate administrative penalties on broker-dealers who involve themselves in insider trading practices. ${ }^{69}$ As earlier stated, ${ }^{70}$ the SEC was empowered to impose treble civil penalties on insider trading offenders for the profit made or loss avoided as a result of their illicit trading. ${ }^{71}$ However, these sanctions were still insufficient for deterrence purposes and it was generally assumed that many persons benefited from insider trading without any fear of incurring liability. This might have been influenced by the fact that insider trading activity is inherently difficult to detect and enforce. ${ }^{72}$

Additionally, the Congress introduced the Insider Trading Sanctions Act to improve inter alia the enforcement of the insider trading ban. The Insider Trading Sanctions Act imposed separate criminal penalties for natural and juristic persons. This Act further increased the criminal penalties for insider trading to a fine of $\$ 100000$ for natural persons and $\$ 500000$ for juristic persons. ${ }^{73}$ The maximum imprisonment term for natural persons remained five years and the civil penalties were unchanged, in spite of the broad powers conferred upon the SEC to claim treble damages from the offenders. These penalties did not deter all persons from knowingly practising insider trading. It remained possible for some unscrupulous persons to benefit from their insider trading practices after paying the stipulated fine or after serving their imprisonment terms.

The Securities Fraud Enforcement Act was adopted and a further amendment especially to criminal sanctions was made in order to improve the enforcement of the insider trading prohibition. ${ }^{74}$ The maximum criminal penalties were increased to a fine of $\$ 1$ million for natural persons and to $\$ 2,5$ million for juristic persons. ${ }^{75}$ Furthermore, the imprisonment sentence was significantly increased to a period not exceeding ten years. ${ }^{76}$ Notably, the prior version of the criminal fines for insider trading applied only to matters relating to stock exchanges. ${ }^{77}$ The Securities Fraud Enforcement Act enabled the SEC to continue paying bounty rewards to anyone who bona fide provided information leading to civil

\footnotetext{
${ }^{61} S 78(2)(a)$ read with subsection (3)(a) \& s 82.

$62 S 78(4)(a)$.

${ }^{63} S 78(5)$.

${ }^{64}$ Put differently, although the current South African insider trading ban has extra-territorial application, it is mainly limited to securities listed on a regulated market in South Africa or elsewhere. Moreover, this extra-territorial application is still to be successfully enforced in South Africa and/or elsewhere because it is, inter alia, not restricted to instances where a territorial link is present by virtue either of the fact that the offender is at the time physically present in South Africa, or was acting through an agent who is in South Africa or by virtue of the prohibited conduct occurring in South Africa. See $s 77$ read with ss 78 $\& 82$ of the Financial Markets Act.

65 See related remarks above.

${ }^{66}$ In relation to this, there are no incentives, bounty rewards and/or whistleblowers immunity provisions to encourage all the relevant persons to timeously report insider trading and related violations to the Financial Services Board (the FSB) and/or the Johannesburg Stock Exchange Limited (the JSE). Furthermore, the available defences for insider trading offences are still relatively insufficient.

67 Public Law 22, 48 Stat.74 15 USC 77a-77mm et seq. (2000) as amended, hereinafter referred to as the Securities Act.

${ }^{68}$ S 24 of the Securities Act; see further Kaswell 1989 Bus.Law 169-170 \& Friedman 1990 North Carolina Law Review 466-494.

${ }^{69}$ For example the SEC was permitted to impose the so-called "watchdog" penalties on offenders. Palmiter Securities Regulation 370.

70 See paragraph 2.1 above.

${ }^{71}$ S $21 \mathrm{~A}$ of the Securities Exchange Act.

72 Steinberg 2003 The International Lawyer 169-171; Kaswell 1989 Bus.Law 169-170; Friedman 1990 North Carolina Law Review 466-494 \& Palmiter Securities Regulation 370.

${ }^{73}$ Hazen Federal Securities Law 134-136.

${ }^{74}$ Hazen Federal Securities Law 137-138; also see s 32(a) of the Securities Exchange Act as amended.

${ }^{75}$ Palmiter Securities Regulation 370.

${ }^{76}$ Palmiter Securities Regulation 370.

${ }^{77}$ Friedman 1990 North Carolina Law Review 466-494; Hazen Federal Securities Law 134-136 \& also see s 32(a) of the Securities Exchange Act as amended.
} 
penalties in order to encourage all persons to expose insider trading activities. ${ }^{78}$ The Securities Fraud Enforcement Act further expanded civil penalties to cover not only insiders or tippers, but also to apply to "controlling persons" to prevent potential insider trading and tipping by their employees. ${ }^{79}$ In other words, this Act empowered the SEC to impose civil penalties on "controlling persons" who are not broker-dealers per se or investment advisors like banks, accounting firms and financial publishers. ${ }^{80}$ Civil penalties imposed on "controlling persons" could differ to some extent from those that may be imposed on "controlled persons". ${ }^{81}$ The civil or administrative penalties that could be imposed on "controlling persons" were generally limited to a fine not exceeding $\$ 1$ million. 82

Furthermore, the Sarbanes-Oxley Act ${ }^{83}$ increased the insider trading sanctions to a maximum fine of $\$ 5$ million for natural persons and up to $\$ 25$ million for juristic persons and a maximum imprisonment sentence of 20 years. ${ }^{84}$ The criminal sanctions and the civil remedies are enforced by the Department of Justice and the SEC respectively. This resulted in more successful criminal prosecutions and civil settlements to be obtained by the courts and the SEC respectively. 85

In 2010, the Dodd-Frank Act empowered the SEC to recover monetary penalties in cease-and-desist administrative proceedings involving commodities or securities (including insider trading) violations. ${ }^{86}$ Nonetheless, the Dodd-Frank Act does not have specific penalties for insider trading practices. ${ }^{87}$

Notably, South Africa also provides for civil, ${ }^{88}$ criminal ${ }^{89}$ and unlimited administrative ${ }^{90}$ penalties for insider trading under the Financial Markets Act. The aforesaid civil and unlimited administrative penalties are mainly enforced by the FSB ${ }^{91}$ and the Enforcement Committee (the EC) ${ }^{92}$ respectively. ${ }^{93}$ Nevertheless, the Financial Markets Act only provides a few criminal penalties, namely, a fixed maximum fine of R50 million, or imprisonment for a period not exceeding ten years, or both such fine and imprisonment against the offenders. ${ }^{94}$ Furthermore, no distinction has been made in relation to the penalties imposed on natural and juristic persons to increase deterrence ${ }^{95} \mathrm{In}$ a nutshell, more may still need to be done to increase the successful investigation, prosecution and settlement of insider trading cases in South Africa. ${ }^{96}$

\subsection{Available Remedies for Insider Trading}

One of the most far reaching insider trading regulatory developments in the US is the availability of a wide range of

${ }^{78} \mathrm{~S} 21 \mathrm{~A}(\mathrm{e})$ which was later repealed and replaced by s $21 \mathrm{~F}$ of the Securities Exchange Act as amended. Also see Palmiter Securities Regulation 370; Hazen Federal Securities Law 137-138 \& Morrison \& Foerster 2010 Year End Review 12-14.

${ }^{79}$ S 21A(a)(3) read with subsection (2) of the Securities Exchange Act as amended. Also see Friedman 1990 North Carolina Law Review 466-494 \& Hazen Federal Securities Law 137-138.

${ }^{80}$ S 21A(a)(1); (2) \& (3) read with s 21A(b) of the Securities Exchange Act as amended. Also see Friedman 1990 North Carolina Law Review $466-494$ \& Hazen Federal Securities Law 137-138.

81 This usually refers to employees or any other persons influenced or managed by another person.

${ }^{2}$ See Friedman 1990 North Carolina Law Review 466-494; Hazen Federal Securities Law 137-138 \& also see s 21A(a)(3) of the Securities Exchange Act as amended.

${ }^{83}$ Notably, this Act was named after its sponsors Senator Paul Sarbanes and the United States of America Representative, Michael G Oxley. Moreover, the Sarbanes-Oxley Act was enacted in response to major corporate and accounting scandals involving companies such as Enron, Tyco International, Adelphia, Peregrine Systems and WorldCom. In addition, the Sarbanes-Oxley Act was enacted in bid to restore public investor confidence, especially after the aforesaid scandals had caused the share prices of the affected companies to collapse, giving rise to a number of investors losing their profits. See Anonymous "History and Context of the Events Contributing to the Adoption of the Sarbanes-Oxley Act" <http://en.wikipedia.org/wiki/Sarbanes\%E2\%80\%930xley_Act\#History_and_context:_events _contributing_to_the_adoption_of_Sarbanes.E2.80.930xley> (accessed 12-06-2012), for further related analysis.

${ }_{84}$ S 306(a); s 1348 to s 1350. Also see Palmiter Securities Regulation 369-370.

${ }^{85}$ The increase in settlements and prosecutions were also enhanced in part by the fact that the courts have the discretion to impose, in light of the facts and relevant circumstances other additional penalties. See for example SEC v Texas Gulf Sulphur Company (1968) 401 F2d 833 (2d Cir); Dirks v SEC (1983) 463 US 646-655; United States v O'Hagan 2199; United States v Falcone [2001 Transfer Binder] 91489 Fed Sec L Rep CCH (2d Cir) \& SEC v Yun (2003) 327 F3d 1263 ( $11^{\text {th }}$ Cir).

${ }^{86}$ Morgan Lewis "2009 Year in Review: SEC and SRO Selected Enforcement Cases and Developments Regarding Broker-Dealers" 201014 <http://www.morganlewis.com/lit_SECandYearlyReviewWP_Jan2010.pdf> (accessed 10-06-2013).

${ }^{87}$ See $s 746$ of the Dodd-Frank Act.

${ }^{88} \mathrm{~S} 82$.

${ }^{89} S$ 109(a)

90 S 99.

${ }^{91} \mathrm{~S} 84$ of the Financial Markets Act.

${ }^{2} \mathrm{~S} 99$ of the Financial Markets Act.

${ }^{93}$ These bodies have relatively similar regulatory and enforcement roles as those of the SEC.

${ }_{94} S$ 109(a).

${ }^{95}$ S 109 (a) of the Financial Markets Act.

${ }_{96}$ See the FSB Annual Report 20114 99-101; the FSB Annual Report 20133 128-130. 
remedies to all the affected persons ${ }^{97}$ For example, a private right of action is available to contemporaneous purchasers or sellers of securities against insider trading offenders. ${ }^{98}$ The affected persons may claim damages not exceeding the profit gained or loss avoided by the defendant (offender) or his tippees..$^{99}$ It is clear that tippers and tippees are jointly and severally liable for insider trading damages. ${ }^{100}$ Nevertheless, any losses incurred or amounts used in a SEC injunction action relating to any civil penalty transaction for contemporaneous traders are deducted from the damages recovered. ${ }^{101}$ No limit or condition is imposed on any person who brings an action to enforce the provisions of the Securities Exchange Act or on the availability of any implied right of action under the same Act.102

In addition, the SEC can bring a judicial enforcement action seeking a court order that enjoins insiders or tippees from indulging in insider trading activity and that mandates them to return or disgorge all the profits gained or losses avoided. ${ }^{103}$

Another remedy available in the US is the civil action for recovery or compensation for "defrauded" owners of nonpublic confidential information. Such persons are statutorily allowed to take a private action against any persons who practise insider trading and other similar activities. ${ }^{104}$ The entities like companies are also allowed to recover any losses suffered as a result of insider trading from the offenders. ${ }^{105}$ There is no explicit statutory limitation that applies to the period on which private actions may be instituted under Rule 10b-5. Instead, the courts have been required to determine the appropriate limitation periods on private civil actions giving regard to any other relevant factors. ${ }^{106}$

The SEC may also claim treble civil damages from any person who violates its insider trading rules. ${ }^{107}$ These damages, like any other remedies, are usually paid into the federal treasury. It is possible for offenders to disgorge their profits in a private or SEC action and still pay a treble damage penalty without any concerns of double jeopardy violation. ${ }^{108}$ The Dodd-Frank Act further allows the SEC to pay bounty rewards to whistle-blowers who report insider trading and related violations that results in the successful disgorgement of profits, monetary penalties and prejudgment interest exceeding $\$ 1$ million in any judicial or administrative proceedings. 109

Similarly, as is the position in the US, ${ }^{110}$ the enforcement of the civil remedies and penalties in South Africa is mainly a responsibility of an independent board, the FSB. ${ }^{111}$ However, administrative remedies are generally administered by the EC, which is a committee of the FSB. For instance, the EC may impose against the insider trading offender, an administrative sanction not exceeding the profit made or loss avoided by that offender. ${ }^{112}$

Moreover, the Financial Markets Act also provides compensatory damages for an amount of up to three times the profit made or loss avoided by the offender, ${ }^{113}$ to those prejudiced by insider trading activities. Thus, any person affected by insider trading activities may institute a claim for part of the proceeds and/or compensatory damages from the FSB under the Financial Markets Act.114 Moreover, the Financial Markets Act now allows the affected persons to claim extra compensatory damages proceeds for an amount of up to R1 million ${ }^{115}$ from the FSB. ${ }^{116}$ Likewise, insider trading victims may also recover part of the proceeds obtained by the FSB from the offenders, in relation to any interests, investigation

\footnotetext{
97 Palmiter Securities Regulation 369-370 \& Friedman 1990 North Carolina Law Review 466-494.

98 S 20 A of the Securities Exchange Act as amended by s 5 of Securities Fraud Enforcement Act. Also see Blue Chip Stamps v Manor Drug Stores (1975) 421 US 723, where the actual affected persons were allowed to bring a private action in terms of Rule 10b-5 against the insider trading offenders.

${ }^{99}$ Elkind v Liggett and Myers Inc (1980) 635 F2d 156(2d Cir) 172-173; FMC Corp v Boesky (1988) 852 F2d 981 (7th Cir), the court held that the affected company was entitled to claim its damages from the insider trading offenders, but nevertheless the tippee was controversially not found guilty because such company did not suffer actual loss. Also see Friedman 1990 North Carolina Law Review 466-494.

100 S 20A(c) of the Securities Exchange Act; also see Friedman 1990 North Carolina Law Review 466-494.

101 S 20A(b)(2) of the Securities Exchange Act; also see Friedman 1990 North Carolina Law Review 466-494 \& Palmiter Securities Regulation 369.

102 Kaswell 1989 Bus.Law 167-169.

${ }^{103}$ SEC v Texas Gulf Sulphur Company 833. In this case it was inter alia postulated that a separate fund be established from which the prejudiced shareholders and other contemporaneous traders could recoup their losses or be compensated from any money recovered from the offenders. Also see generally Palmiter Securities Regulation 369-370.

${ }_{104}$ Rule 10b-5. See further Palmiter Securities Regulation 369.

105 Palmiter Securities Regulation 369. Also see FMC Corp v Boesky 981.

106 Friedman 1990 North Carolina Law Review 466-494.

107 Rules 10b-5 \& 14e-3.

108 Palmiter Securities Regulation 370. See further SEC v Levine (1986) 86 Civ 3726 (SDNY) (RO) \& SEC v Boesky (1986) 86 Civ 8767.

109 S 922(a) of the Dodd-Frank Act; also see Morrison \& Foerster 2010 Year End Review 13-14 \& Morgan Lewis 201014 $<$ http://www.morganlewis.com/lit_SECandYearlyReviewWP_Jan2010.pdf> (accessed 10-06-2013).

110 See related remarks above.

111 See s 84 read with s 82 of the Financial Markets Act

112 See $s$ 82(1)(a); (2)(a).

113 See $s$ 82(1)(b); (2)(b).

114 See $s$ 82(4)(b) read with subsections 5 \& 6 .

115 See s 82(1)(b); (2)(b).

116 See $s$ 82(1)(b); (2)(b).
} 
costs, legal costs and commission ${ }^{117}$ as determined by the EC under the Financial Markets Act. ${ }^{118}$ The Financial Markets Act also provides actual calculable damages which may be utilised by those who fall victim to insider trading practices. ${ }^{119}$ However, unlike the position in the US, ${ }^{120}$ the Financial Markets Act does not provide any new measures or statutory guidelines that could be employed by the EC and/or the claims officer when determining the actual calculable damages that will be given to the affected persons. ${ }^{121}$ Furthermore, the Financial Markets Act's insider trading remedies are still very few, and they could also be less dissuasive for deterrence purposes.122 For instance, unlike the situation in the US, ${ }^{123}$ other alternative remedies such as specific civil pecuniary penalties, punitive damages, bounty rewards, class actions and private rights of action are not expressly provided under the Financial Markets Act. ${ }^{124}$

\subsection{Prohibition on Market Manipulation}

\subsubsection{Prohibition on Trade-Based and Disclosure-Based Market Manipulation}

Although the concept of market abuse is not expressly and statutorily defined in the US, ${ }^{125}$ the regulation and prohibition of market abuse practices can be linked back to the so-called "New Deal" legislation that was enacted after a heavy crash occurred in its stock markets in 1929.126 The most important "New Deal legislation" was the Securities Act and the Securities Exchange Act.

The Securities Act prohibits the making of corporate misstatements that will lead to the defrauding of innocent investors. ${ }^{127}$ This is mainly done to protect investors against corporate false or misleading statements in the context of new issues and to safeguard the adequate and continuous flow of issuer-specific information. ${ }^{128}$

In addition, the Securities Exchange Act expressly prohibits market manipulation. This Act, for instance, prohibits any person from willingly creating misleading appearances of active trading in securities listed on a stock exchange. ${ }^{129}$ Put differently, the Securities Exchange Act discourages and prohibits a number of activities that create or that might create a misleading appearance of trading in listed securities like wash sales and matched orders (when the same person or affiliate is essentially both the buyer and the seller of the securities in question), a series of transactions to induce the purchase or sale by others and the false or reckless "touting" or spreading of rumours by broker-dealers or other traders to induce trading in such securities. ${ }^{130}$

The Securities Exchange Act further prohibits any person from directly or indirectly using manipulative and other deceptive devices to purchase or sell any listed securities to the detriment of investors. ${ }^{131}$ In addition, any such persons who violate the rules and regulations proscribed by the SEC will also be liable for an offence. ${ }^{132}$ In relation to this, the SEC is authorised to make any other appropriate rules and regulations to combat market manipulation in the US. ${ }^{133}$ The SEC introduced a rule that discourages any person from employing any device, scheme or artifice to defraud or to engage in an act, practice or course of business that will deceive other persons. ${ }^{134}$ This rule further prohibits all persons from making untrue and misleading statements relating to the material facts of any securities. ${ }^{135}$

\footnotetext{
117 See $s$ 82(2)(e).

118 See $s$ 82(1)(c) \& (d); (2)(c) \& (d).

119 See $s$ 82(6)(a) and (b).

120 See related analysis above.

121 See further s 82(6)(a) \& (b) read with subsection (5)(b).

122 See $s 82$.

${ }^{123}$ See earlier related remarks above.

124 See $s 82$

${ }^{125}$ Avgouleas The Mechanics and Regulation of Market Abuse 104.

${ }^{126}$ Avgouleas The Mechanics and Regulation of Market Abuse 174-175.

127 S 17.

${ }^{128}$ Avgouleas The Mechanics and Regulation of Market Abuse 174.

${ }^{129}$ S 9(a). Also see Palmiter Securities Regulation 266.

$130 S 9(a)$.

131 S 10(b) read with subsection (a). See further Friedman 1990 North Carolina Law Review 466-494; Avgouleas The Mechanics and Regulation of Market Abuse 104

132 S 9(b) \& (c) read with subsection (a) of the Securities Exchange Act.

${ }_{133}$ For example the United States Securities and Exchange Commission promulgated Rule 10b-5 in order to effectively enforce the provisions of $s$ 10(b) of the Securities Exchange Act. See further Avgouleas The Mechanics and Regulation of Market Abuse 104.

134 See Rule 10b-5 which prohibits three types of market manipulation, namely false dissemination of material information relating to securities, distortion and misleading behaviour and the use of manipulative devices that negatively affect the price of securities and create a false appearance in the market activity. Also see Palmiter Securities Regulation 316-317 \& Barnes Stock Market Efficiency, Insider Dealing and Market Abuse (2009) 132.

${ }_{135}$ Rule 10b-5. Also see Palmiter Securities Regulation 306; 308-309.
} 
Moreover, the SEC introduced Regulation $\mathrm{M}^{136}$ which, among other aspects, prohibits market manipulation during a public distribution (public offering of securities) and allows price-stabilisation activities only in some specific circumstances. The SEC further adopted Rule 10a-1 (the so-called up-tick rule) to prevent market manipulation and free falls in stock prices due to short selling in a falling market. ${ }^{137}$ This rule has been criticised as too narrow because it did not cover short sales and other manipulative activities in over the counter markets and in sales of derivatives. Regulation $\mathrm{SHO}$ was then enacted to combat naked short selling and market manipulation in all the US's financial markets and in broker-dealer transactions. ${ }^{138}$

The Securities Exchange Act further prohibits the making of false or misleading statements of any material fact or engagement in any fraudulent, deceptive or manipulative practices in connection with tender offers. ${ }^{139}$ Additionally, the Securities Exchange Act allowed the SEC to define "fraudulent, deceptive or manipulative practices" and to make appropriate rules designed to prevent such manipulative practices. ${ }^{140}$ This Act does not expressly prohibit market manipulation in over the counter markets. ${ }^{141}$

In an effort to avoid the recurrence of corporate scandals ${ }^{142}$ and to reassure investors that the US financial markets will be free from market abuse practices, the Sarbanes-Oxley Act was enacted. ${ }^{143}$ This Act prohibits any person (including a juristic person) or employee from engaging in an act or practice that will improperly influence the conduct of audits or the falsification of books, records and accounts. ${ }^{144}$ The Sarbanes-Oxley Act further prohibits senior officers of a company from selling stocks during certain pension "black-out" periods if they received that stock as compensation during their employment with the company in question in order to prevent possible market abuse activities like insider trading and market manipulation. ${ }^{145}$ Additionally, the SEC enacted a specific rule that prohibits officers, directors and persons acting under their direction from knowingly coercing, manipulating, misleading or fraudulently influencing the auditor of the issuer's financial statements. ${ }^{146}$

Interestingly, the Financial Markets Act, like its US counterpart, the Securities Exchange Act, prohibits any person from knowingly engaging or participating in trade-based market manipulation practices that interfere with the normal market mechanisms of supply and demand for securities. ${ }^{147}$ Notably, the Financial Markets Act employs the term "knowingly" in its trade-based market manipulation provision ${ }^{148}$ and this could imply that proof of intention is mandatorily required before any liability can be imposed upon the offenders. Furthermore, the Financial Markets Act's disclosurebased market manipulation provisions, ${ }^{149}$ like similar provisions in the US, ${ }^{150}$ prohibit all persons from making or publishing false, misleading or deceptive statements, promises or forecasts that relate to any security. ${ }^{151}$ Nonetheless, the Financial Markets Act does not expressly prohibit a person who inadvertently aided or abetted another person to make or publish a false, misleading or deceptive statement, promise or forecast that relate to any security. 152 For instance, where a printing company inadvertently aided or abetted an offender by ignorantly printing and/or publishing his misleading or deceptive materials pertaining to listed securities, to the detriment of other uninformed investors. In other

13617 CFR, s 241.100-240.105 (2007). The SEC normally relies on its wide powers as conferred by s 10(b) of the Securities Exchange Act. See further Palmiter Securities Regulation 267-268 \& Hazen Federal Securities Law 89-91.

137 Palmiter Securities Regulation 268-269.

${ }_{138}$ Palmiter Securities Regulation 269.

${ }_{139} \mathrm{~S} 14(\mathrm{e})$ of the Securities Exchange Act.

140 For example the SEC adopted Rule 14e-3 to enhance the enforcement of the provisions of s 14(e) of the Securities Exchange Act and a number of measures that discourage market manipulation were introduced. Rule 14e-3(a) \& (d). Also see Friedman 1990 North Carolina Law Review 466-494.

${ }^{141}$ Nelemans "Redefining Trade-Based Market Manipulation" 2008 Valparaiso University Law Review 1169 1171-1172.

142 SEC v WorldCom Inc (2003) 02 Civ 4963(JSR).

${ }^{143}$ Mossos "Sarbanes-Oxley goes to Europe: A Comparative Analysis of United States and European Union Corporate Reforms after Enron" 2004 Currents International Trade Law Journal 9 9-10. For further related comments and analysis see Anonymous <http://en.wikipedia.org/wiki/Sarbanes\%E2\%80\%930xley_Act\#History_and_context:_events_contributing_to_the_adoption_of_Sarbanes.E2.80.930xley> (accessed 12-06-2012), who also submits that the Sarbanes-Oxley Act was inter alia enacted in bid to restore public investor confidence in the aftermath of several corporate and accounting scandals which affected companies such as Enron, Tyco International, Adelphia, Peregrine Systems and WorldCom in the US.

144 S 303(a).

145 S 306(a)(1).

146 The Sarbanes-Oxley Act empowers the SEC to make further rules that it may deem necessary for the purposes of enforcing the market abuse provisions, see Rule 13b-2; Rule 13b2-2(b)(1). Also see Mossos 2004 International Trade Law Journal 9-11.

147 S 80(1). Moreover, the provisions of s 80(3) goes a bit wider than s 10(b) of the Securities Exchange Act by deeming a number of trading practices to be regarded as manipulative in South Africa. Also see Cassim "An Analysis of Market Manipulation under the Securities Services Act 36 of 2004 (part 1)" 2008 SA Merc LJ 33 52-60.

148 S 80(1).

$149 \mathrm{~S} 81$.

150 S 9(a)(4) of the Securities Exchange Act.

151 See s 81; also see Cassim "An Analysis of Market Manipulation under the Securities Services Act 36 of 2004 (part 2)" 2008 SA Merc LJ 177 179-180.

152 S 81 \& also see Cassim 2008 SA Merc LJ 178. 
words, it was inter alia held in Central Bank of Denver NA v First Interstate Bank of Denver NA ${ }^{153}$ that the words "directly or indirectly" do not apply to secondary actors who are not directly involved in market manipulation practices like aiders and abettors. Therefore, if we are to follow the approach employed in this case, the words "directly or indirectly" as stated in the Financial Markets Act's disclosure-based market manipulation provisions ${ }^{154}$ could be interpreted to exclude aiders and abettors.

\subsubsection{Prohibition on Commodity Market Manipulation}

Market manipulation with respect to commodities futures and other kinds of derivatives is principally regulated under the Commodity Exchange Act. ${ }^{155}$ Thus, the CFTC, and not the SEC, is the main regulatory body that deals with the enforcement of commodity market manipulation in the US. ${ }^{156}$ Actual or attempted market manipulation of any commodity or future or option is prohibited under the Commodity Exchange Act as amended. ${ }^{157}$ Consequently, any conduct or practice that results in the misleading of investors and the creation of an artificial price of commodities is prohibited. ${ }^{158}$ The Commodity Exchange Act further prohibits intentional aiding, abetting and inducement of other persons to commit market manipulation offences. ${ }^{159}$ Under this Act, the CFTC could bring a civil action or any other appropriate action against the offenders if it has a reason to believe that such offenders have a specific intent to create an artificial price or to influence the price of the commodities or that an artificial price that exists has been caused by their manipulative practices. ${ }^{160}$

The Commodities Futures Modernization Act prohibits commodities-based market manipulation in the single-stock futures markets and over the counter derivative transactions. ${ }^{161}$ Accordingly, under this Act both the CFTC and the SEC have the authority to institute appropriate proceedings against any person who commits market manipulation and other related activities. ${ }^{162}$ Notably, the SEC's authority is only limited to violations relating to single-stock futures transactions, not "broad-based" security futures transactions which are exclusively covered by the CFTC. ${ }^{163}$ Nonetheless, if there is a rule violation or market manipulation in the sale or purchase of a single-stock future, either the CFTC or the SEC may, after consultation, bring an enforcement action against the offenders. ${ }^{164}$

Recently, the Dodd-Frank Act broadened the authority of the CFTC to make appropriate rules ${ }^{165}$ and prohibit both trade-based market manipulation and disclosure-based market manipulation practices. ${ }^{166}$ In addition, the Dodd-Frank Act introduced the prohibition on fraud-based market manipulation practices in relation to any purchase or sale of a swap or commodity contract in interstate commerce or for future delivery and/or subject to the rules of any registered entity. 167 The Dodd-Frank Act further introduced a broad prohibition on direct or indirect swap or commodity-based market manipulation as well as attempted swap or commodity-based market manipulation. ${ }^{168}$

Unlike the status quo in the US, ${ }^{169}$ the Financial Markets Act does not have provisions that specifically prohibit commodity-based market manipulation in South Africa. ${ }^{170}$ Apparently, commodity-based market manipulation practices are prohibited and enforced by both the JSE and the FSB. Nonetheless, in contrast with the CFTC, ${ }^{171}$ it remains to be

\footnotetext{
153 (1994) 511 US 164 (US SC) 170-171

154 S 81 \& also see Cassim 2008 SA Merc LJ 178.

155 See the CFTC \& the SEC Report 16 October 2009 56-57.

156 The CFTC was established pursuant to the Commodity Futures Trading Commission Act of 1974 (Public Law 93-64, 88 Stat. 1398). Avgouleas The Mechanics and Regulation of Market Abuse 106.

157 S 9(a)(2).

${ }^{158}$ All persons are prohibited from entering into or confirming the execution of a transaction that is misleading in nature (wash sales) to create a fictitious sale of any commodities, see s 4(c). Also see Swan Market Abuse Regulation (2006) 192-194.

159 Ss 13(a); 6(c) to (d) \& 9(a)(2); also see Avgouleas The Mechanics and Regulation of Market Abuse 104.

${ }_{160}$ Avgouleas The Mechanics and Regulation of Market Abuse 104; Swan Market Abuse Regulation 192-194.

${ }_{161}$ Knepper 2004 Pierce Law Review 36-37.

162 See generally s 251 of the Commodities Futures Modernization Act; also see Knepper 2004 Pierce Law Review 36.

163 S 201 of the Commodities Futures Modernization Act; also see Knepper 2004 Pierce Law Review 37.

164 Ss 204; 251 of the Commodities Futures Modernization Act; also see Knepper 2004 Pierce Law Review 37-38.

165 See the CFTC Proposed Rules 180.1 \& 180.2; also see Morrison \& Foerster 2010 Year End Review 15.

${ }^{166} S 753$ of the Dodd-Frank Act which amended s 6(c) of the Commodity Exchange Act. It is stated that s 753 of the Dodd-Frank Act was originally modeled upon the Derivatives Market Manipulation Prevention Act of 2009 which was introduced by Senator Cantwell in 2009, see generally related remarks by Cantwell "Senate Passes Cantwell Anti-Manipulation Amendment" (06-05-2010) <http://cantwell.senate.gov/news/record.cfm?id=324761> (accessed 26-112013).

${ }_{167}$ S 753 of the Dodd-Frank Act which amended s 6(c) of the Commodity Exchange Act.

${ }_{168}$ S 753 of the Dodd-Frank Act which amended s 6(c) of the Commodity Exchange Act; also see Morrison \& Foerster 2010 Year End Review 15.

169 See the earlier discussion in paragraphs above.

170 Ss $80 \& 81$.

171 See the earlier discussion in paragraphs above.
} 
seen whether the JSE and the FSB will consistently increase the prohibition and surveillance of commodity-based market manipulation practices in South Africa. ${ }^{172}$ Furthermore, it is uncertain whether the FSB prohibits Internet-based market manipulation activities. For instance, unlike the SEC, the FSB does not have a specific unit that prohibits Internet-based market abuse activities. ${ }^{173}$

\subsection{Available Penalties for Market Manipulation}

A variety of penalties such as criminal, civil and administrative sanctions are used to combat market manipulation practices in the US. The Securities Act imposes criminal penalties of up to five years imprisonment and a $\$ 10000$ fine on any person who knowingly violates its anti-fraud and market manipulation provisions. ${ }^{174}$ Furthermore, the Securities Exchange Act imposes a maximum criminal penalty fine of $\$ 100000$, or imprisonment for a period not exceeding five years, or both on natural persons who wilfully engage in prohibited trade practices and other related market manipulation offences. ${ }^{175}$ The Securities Exchange Act further imposes a separate fine not exceeding $\$ 5$ million, or imprisonment for a period of up to 20 years on individuals as well as a $\$ 25$ million fine for juristic persons (companies and other entities) that intentionally engage in disclosure-based market manipulation and other related practices. ${ }^{176}$ This distinction is believed to have been made to increase deterrence and improve the general enforcement of the market abuse provisions in the US. ${ }^{177}$ Importantly, both the Securities Act and the Securities Exchange Act criminalised false and misleading registration statements and the filing of misleading documents with the SEC respectively. ${ }^{178}$

With regard to civil penalties, the Securities Exchange Act has empowered the SEC to impose civil penalties on any person who wilfully or recklessly aided, abetted, counseled, commanded or induced another person to commit market abuse practices like filing false and misleading documents with the SEC. ${ }^{179}$ Although there is no explicit provision for a civil penalty for the contravention of Rule 10b-5, a private right of action for such contravention is available to all prejudiced actual purchasers and sellers of securities on the basis of equity. ${ }^{180}$

In relation to administrative penalties, the SEC is further authorised to administer and impose unlimited administrative penalties upon the market manipulation offenders. It may issue a refusal or stop order (cease and desist orders) to prevent an already existing registration statement from being effective or to stop the filing of a false or misleading statement. ${ }^{181}$ The SEC may also claim the disgorgement of any profits made by a person who violates the securities and market abuse provisions. ${ }^{182}$ In addition, the SEC may impose a judicial order for civil monetary penalties on the alleged offenders if it reasonably believes that such penalties will be in the public interest. ${ }^{183}$

On the other hand, the Commodities Futures Modernization Act provides criminal penalties against any commodities-based market manipulation offenders in the single-stock futures markets, over the counter commodities derivatives and other related markets in the US. Similarly, the Commodity Exchange Act imposes a criminal penalty fine of up to $\$ 100000$ on individuals and up to $\$ 500000$ on entities that indulge in fraudulent and/or other prohibited commodities-based market manipulation practices. Individuals could also be liable to imprisonment for up to five years, or both such fine and imprisonment. ${ }^{184}$ In addition, the Commodity Exchange Act imposes civil penalties against any commodities-based market manipulation offenders. This Act allows the CFTC to take appropriate civil action against any persons who aids, abets, counsels, induces or procures the commission of market manipulation offences. ${ }^{185}$ The CFTC may, therefore, claim any disgorgement profits and civil monetary penalties of up to $\$ 1$ million or three times the profits

\footnotetext{
172 See Myburgh \& Davis (25-03-2004) 13 <http://www.genesis-analytics.com/public/FSBReport.pdf> (accessed 09-02-2013).

173 On the other hand, the SEC introduced the Office of Internet Enforcement to inter alia combat Internet-based market abuse practices. See further Cassim 2008 SA Merc LJ 182-183.

174 S 24. Also see Palmiter Securities Regulation 452.

175 S 32(c)(2)(A) read with subsection (a) of the Securities Exchange Act; also see Palmiter Securities Regulation 451-454.

176 These criminal penalties are mainly enforced by the Department of Justice. S 32(a) of the Securities Exchange Act as amended by the Sarbanes-Oxley Act.

177 Palmiter Securities Regulation 451-455

${ }_{178} S 32$ of the Securities Exchange Act \& s 24 of the Securities Act; also see Palmiter Securities Regulation 452- 453.

179 S 21(d)(3) of the Securities Exchange Act; see further s 20(d) of the Securities Act.

180 Cassim 2008 SA Merc LJ 192-193.

${ }^{181}$ For example, the SEC may impose a cease and desist order compelling any alleged offender to stop committing further market abuse violations. Ss $8 A$; 8(b) \& (d) of the Securities Act \& s 21C of the Securities Exchange Act. Also see Palmiter Securities Regulation 436-444.

182 S 8A(e) of the Securities Act; s 21B(e) of the Securities Exchange Act. Also see further Palmiter Securities Regulation 438.

${ }_{183}$ S 21(d)(3) of the Securities Exchange Act; see further s 20(d) of the Securities Act; also see Palmiter Securities Regulation 441-442.

184 See generally s 13(a) read with subsection (c)(a) of the Commodity Exchange Act.

185 S 25(a)(1).
} 
gained by offenders and distribute them to the affected persons. ${ }^{186}$

Additionally, the Sarbanes-Oxley Act introduced significantly higher criminal penalties for market manipulation and other related offences. It imposes a maximum criminal fine of $\$ 5$ million and imprisonment sentence of up to 20 years for individuals. ${ }^{187}$ A separate maximum criminal fine not exceeding $\$ 25$ million is also imposed on entities that are involved in market manipulation and other related activities. ${ }^{188}$ The Sarbanes-Oxley Act further provides civil penalties against any person who knowingly executes or attempts to execute a scheme or artifice to defraud or to manipulate by means of false pretenses, representations or promises, any money or property in connection with the securities of a public company. ${ }^{189}$ This suggests that there is an attempted market manipulation offence in the US. The Sarbanes-Oxley Act permits the SEC to seek civil compensatory penalties against any person who presents manipulative, fraudulent, false or misleading statements with regard to the conduit of audits, books, records and accounts of a company. ${ }^{190}$ The SEC may impose other civil and administrative penalties necessary to enforce and discourage market manipulation activities. ${ }^{191}$

As is the position in the US, ${ }^{192}$ the Financial Markets Act also imposes criminal ${ }^{193}$ and unlimited administrative ${ }^{194}$ penalties against any person who indulges in trade-based market manipulation ${ }^{195}$ and disclosure-based market manipulation ${ }^{196}$ practices in South Africa. These criminal and unlimited administrative penalties are generally enforced by the courts and the EC ${ }^{197}$ respectively. Nevertheless, as stated earlier, ${ }^{198}$ the Financial Markets Act still imposes a few and minimal criminal penalties of a fixed maximum fine of R50 million, or imprisonment for a period not exceeding ten years, or both such fine and imprisonment ${ }^{199}$ against the market manipulation offenders. Unlike the position in the US, relatively few investigations ${ }^{200}$ and criminal prosecutions involving market manipulation cases have been obtained in the relevant courts in South Africa to date. ${ }^{201}$ As previously indicated, ${ }^{202}$ this could be aggravated by the fact that the Financial Markets Act does not impose sufficient, separate and distinct criminal penalties against the natural and juristic persons that commit market manipulation offences to increase deterrence. ${ }^{203}$

Moreover, the Financial Markets Act does not expressly provide civil penalties for market manipulation offences. ${ }^{204}$ This flaw could be negatively affecting the curbing of market manipulation practices in South Africa, ${ }^{205}$ compared to similar foreign legislation in countries like the US.

Additionally, unlike the situation in the US, ${ }^{206}$ little or no consideration was given to the introduction of specific civil penalties for commodities-based market manipulation practices in South Africa. ${ }^{207}$ Moreover, although it appears that the

${ }^{186} S 6(c)(10)(C)$ as amended by s 753(a) of the Dodd-Frank Act. The profits disgorged and the penalties recovered are normally kept in a fund or trust controlled by the CFTC for purposes of offering compensatory aid to all the prejudiced persons.

187 S 807.

188 Palmiter Securities Regulation 452.

${ }^{189}$ Avgouleas The Mechanics and Regulation of Market Abuse 458.

190 S 303(a). See further Rule 13b2-2(b)(1) \& Rule 13b2-2(b)(2).

191 There is no express statutory limitation on SEC's enforcement actions. Palmiter Securities Regulation 436-444.

192 See earlier remarks in paragraphs above.

193 S 109(a).

${ }^{194}$ Notably, these administrative sanctions are provided for in terms of the Financial Institutions (Protection of Funds) Act 28 of 2001, hereinafter referred to as the Protection of Funds Act, but no similar provisions are found in the Financial Markets Act, generally see s 99 .

$195 \mathrm{~S} 80$.

196 S 81; also see Cassim 2008 SA Merc LJ 193-195.

197 Despite this, the EC does not have more discretionary powers with regard to the enforcement of administrative penalties for market abuse. For instance, unlike the position in the US, the EC does not have discretionary powers to impose administrative penalties on the persons who attempt to commit market manipulation offences in South Africa. See s 99 of the Financial Markets Act; see further Cassim 2008 SA Merc LJ 195.

${ }_{198}$ See related remarks in paragraph 2.2 above.

199 S 109(a). Cassim 2008 SA Merc LJ 191-195.

200 For example, during the period between January 1999 and June 2011 only about 14 market manipulation cases were investigated and successfully completed by the Directorate of Market Abuse, see the FSB Annual Report 2011 4 99-101; generally see further the FSB Report (28-06-2011) <http://www.fsb.co.za/ftp://ftp.fsb.co.za/public/documents/AReport2011.pdfs (accessed 22-11-2013); the Financial Services Board "List of Current Investigations of the Directorate of Market Abuse" Media Release (28-06-2011) <http://www.fsb.co.za/ftp://ftp.fsb.co.za/public/documents/AReport2011.pdfs (accessed 22-11-2013), indicates that during the period between March 2007 and April 2010 only four cases involving disclosure-based market manipulation and twelve cases of trade-based market manipulation were investigated and such investigations were still ongoing.

201 See the FSB Annual Report 2013 128-130.

202 See related remarks in paragraph 2.2 above.

${ }^{203} S$ 109(a).

${ }^{204}$ See ss 80 \& 81 read with ss 109(a) \& 82; also see Cassim 2008 SA Merc LJ 192. This suggests that persons who fall victim to market manipulation practices are left to find their own civil remedies. See Cassim 2008 SA Merc LJ 36.

${ }^{205}$ Put differently, there is no specific statutory civil penalty provision for market manipulation violations under the Financial Markets Act, see ss 80 \& 81 read with ss 109(a) \& 82. However, it is generally submitted that the civil penalties for market manipulation may be enforced in terms of the Protection of Funds Act.

${ }^{206}$ See earlier remarks above.

${ }^{207}$ See ss 80 \& 81 read with ss 109(a) \& 82 of the Financial Markets Act. 
enforcement of the commodities-based market manipulation ban vests with both the FSB and the JSE, not many settlements involving such cases have been obtained in the South African courts to date. ${ }^{208}$ It is not clear whether the FSB and the JSE have the statutory authority to impose their own civil penalties and appropriate rules to prevent commodity-based market manipulation. Furthermore, neither the Protection of Funds Act nor the Financial Markets Act has a statutory provision that expressly empowers the EC to make or enact its own rules to enhance the combating of market manipulation practices in South Africa. ${ }^{209}$

\subsection{Available Remedies for Market Manipulation}

A wide range of remedies such as criminal, civil and administrative remedies are available to all the persons affected by market manipulation in the US. Apart from these remedies, a private right of action, damages, injunctions, disciplinary sanctions and suspension orders may be employed by the victims of market manipulation to recover their losses from the offenders.

Criminal remedies may be obtained from any person who contravenes market manipulation provisions or the SEC rules, including the making of a false or misleading statement in a filing submitted to the SEC. ${ }^{210}$ If the offenders refuse or delay to pay up their fines, the SEC will refer such cases to the Department of Justice for further criminal prosecution. ${ }^{211}$

In addition, a statutory derivative civil remedy for market manipulation violations is permitted in the US on grounds of equity. ${ }^{212}$ The SEC may, therefore, claim disgorgement of profits and other civil compensatory remedies from any person who contravenes its rules or other market manipulation provisions. ${ }^{213}$ Likewise, the CFTC may institute court orders for civil monetary fines, restitution, disgorgement of profits, rescission and actual damages against any commodities-based market manipulation offenders. ${ }^{214}$

The SEC and the CFTC are further empowered to take appropriate administrative action against any persons who violate the relevant market manipulation provisions in the US. In relation to this, the SEC may issue cease and desist orders compelling any alleged offenders to stop or refrain from violating its market abuse rules. ${ }^{215}$ If the alleged offender fails to comply with the cease and desist order, the SEC may enforce the order in a federal court. ${ }^{216}$ Furthermore, the SEC may impose a compliance order with regard to any misleading tender offer statements or where a registrant's filing is defective, manipulative or misleading. ${ }^{217}$ The SEC can further suspend trading and offering of securities traded publicly for up to ten days pending a hearing. ${ }^{218}$ In line with this, the SEC can take disciplinary action against broker-dealers and other persons who contravene the market abuse provisions. ${ }^{219}$ In the same way, the CFTC may seek rescission or

208 See generally the FSB Annual Report 2011 99-102; the FSB Annual Report 2013 128-130; also see the FSB "Enforcement Committee Actions" Media Release (28-06-2011) <http://www.fsb.co.za/ftp://ftp.fsb.co.za/public/documents/AReport2011.pdf> (accessed 22-11-2013), which shows that the EC successfully obtained administrative penalties in only about sixteen cases of market manipulation during the period between December 2006 and July 2011 \& see further related remarks in paragraph 2.4.2 above.

${ }^{209}$ S 99 read with ss 80 \& 81 of the Financial Markets Act \& ss 6A to 6l of the Protection of Funds Act. See further the FSB Annual Report 2011 101-102 \& Van Deventer "Harnassing Administrative Law in Encouraging Compliance" 2009 FSB Bulletin 3 4. One can argue that the EC, like the SEC, must have express statutory authority to make additional administrative rules and to take any other action which it reasonably believe will improve the enforcement of the market abuse administrative sanctions in South Africa.

210 The affected persons may obtain criminal remedies of up to $\$ 5$ million and $\$ 25$ million fines for individuals and entities respectively from the offenders. See s 32(a) of the Securities Exchange Act (as amended); 24 of the Securities Act. Also see Palmiter Securities Regulation 452-454.

${ }^{211}$ The fines or monetary remedies recovered by the SEC or the Department of Justice are paid into the treasury account for distribution to all the persons who fall victim to market manipulation and other related market abuse practices. Palmiter Securities Regulation 370; 441.

${ }^{212}$ Cassim 2008 SA Merc LJ 192-193.

${ }^{213}$ The offenders will be liable to pay the SEC civil remedies of up to three times the profit gained or loss avoided as a result of their illicit practices. See $S$ 308 of the Sarbanes-Oxley Act. Also see FMC Corp v Boesky (1987) 673 F2d 272 (ND 111); Blue Chip Stamps v Manor Drug Stores 723; also see Palmiter Securities Regulation 369-370.

${ }^{214}$ S 13a-1(a); (b) \& (d)(1) read with s 22 \& 25 of the Commodity Exchange Act; see further s 6(c)(10)(C) as amended by s 753(a) of the Dodd-Frank Act. ${ }^{215}$ S 8 A of the Securities Act; s 21C of the Securities Exchange Act. Also see WHX Corp v SEC (2004) 362 F3d 854 (DC Cir); Palmiter Securities Regulation 437.

216 The federal courts may impose their own additional civil monetary penalties for non-compliance. The SEC may further impose a cease and desist order to prevent the registration or filing of any documents which contains false, deceptive or misleading statements, see Palmiter Securities Regulation 437.

217 S 15(c)(4) read with ss 15(b)(1)(B) \& 15(b)(4) of the Securities Exchange Act.

${ }^{218} S 12(k)$ of the Securities Exchange Act. The SEC can suspend trading in the affected securities for up to twelve months or revoke the registration of the alleged offender in cases of persistent market abuse violations and non-compliance, see s 12(j) of the Securities Exchange Act; also see SEC v Sloan (1978) 436 US 103 \& Palmiter Securities Regulation 437.

${ }^{219}$ Such action includes claiming monetary administrative fines, revocation of registration and temporary suspension. See further s $21 \mathrm{~B}$ read with s $21 \mathrm{C}$ of the Securities Exchange Act. The SEC may also seek temporary restraining orders, preliminary injunctions, temporary judicial asset freeze of up to 45 days as well as permanent asset freeze against any alleged offenders. See generally s 21(a) to (i) of the Securities Exchange Act. Also see Palmiter Securities Regulation 438-439; 441. 
permanent injunction orders against persistent commodities-based market manipulation offenders. ${ }^{220}$

As stated earlier, ${ }^{221}$ a private right of action is available to all the persons who are prejudiced by market manipulation, insider trading and other related practices to claim their damages directly from the offenders. ${ }^{222}$ For instance, any prejudiced person may have a private right of action against brokers, exchanges and related organisations that commit commodities-based market manipulation offences. Nonetheless, where the costs of bringing such action are too high, the CFTC may claim remedies on behalf of the prejudiced persons. ${ }^{223}$ It is possible that the offenders who engage in trade-based or disclosure-based market manipulation and/or commodities-based market manipulation may be subjected to the SEC or CFTC action as well as another private action from the actual prejudiced persons. ${ }^{224}$

In contrast to the position in the US, 225 there are no specific civil remedies for commodities-based and other related forms of market manipulation practices that are provided in the Financial Markets Act. ${ }^{226}$ In other words, the Financial Markets Act falls short when it comes to the statutory provision and policing of commodities-based market manipulation remedies in South Africa. ${ }^{227}$ On the other hand, the EC may recover administrative damages from the trade-based and/or disclosure-based market manipulation offenders in terms of the Protection of Funds Act. ${ }^{228}$ However, the Financial Markets Act does not expressly empower the EC to provide civil monetary administrative remedies and/or sanctions to compensate persons who fall victim to market manipulation. ${ }^{229}$ As a result, the $\mathrm{EC}$ is currently able to bring only a few administrative actions such as compensatory orders, cost orders and disciplinary orders against the market manipulation offenders. ${ }^{230}$ Furthermore, there is no express statutory provision for a private right of action for market manipulation victims in South Africa. ${ }^{231}$

\section{Concluding Remarks}

It is clear that both the US, at a federal level, 232 and South Africa ${ }^{233}$ have market abuse legislation which mainly discourages insider trading and market manipulation. However, as earlier stated, ${ }^{234}$ the prohibitions, penalties and remedies for market abuse in the US are relatively broader than those available in South Africa. For instance, unlike the position in the US, ${ }^{235}$ Internet-based and commodities-based market manipulation practices are not expressly outlawed in South Africa, especially under the Financial Markets Act. ${ }^{236}$ Furthermore, the Financial Markets Act still does not impose sufficient, separate and distinct criminal penalties against the natural and juristic persons that commit market abuse offences in South Africa. ${ }^{237}$ Over and above, other alternative remedies such as specific civil pecuniary penalties, punitive

\footnotetext{
220 Ss 13a-1(a) \& (b); 13a-1(d)(1) of the Commodity Exchange Act.

221 See paragraph 2.5 above; also see related analysis in paragraph 2.3 above.

222 S 20 A read with s 21A; s 27A \& s 28 of the Securities Exchange Act; s 22 \& s 25 of the Commodity Exchange Act. Also see Cassim 2008 SA Merc LJ $192-193$.

${ }^{223}$ S 25(a) of the Commodity Exchange Act. Although the actual damages that may be imposed against the offenders are not clearly stipulated, it is generally believed that such offenders will be liable to pay the CFTC compensatory damages for the actual loss avoided or profit gained. Therefore, in successful cases, the affected persons will recover their damages from offenders through the CFTC. See Comm 'n v Heffernan (2003) 274 FSupp2d 1375 (SDGa); also see Pearce "Broadening Actual Damages in the Context of the Commodities Exchange Act" 2007 Journal of Law and Policy $449449 ; 480$ \& 483.

${ }^{224}$ This is not viewed as a violation to the double jeopardy clause of the US constitution which asserts that no person may be subjected to multiple prosecutions or punishment of the same conduct. See Palmiter Securities Regulation 460-461.

225 See earlier related remarks above.

${ }^{226}$ See ss 80 \& 81 read with ss 109 (a) \& 82. See related discussion in paragraph 2.5 above; also see related analysis in paragraph 2.3 above

227 See ss 80 \& 81 read with ss 109(a) \& 82. It is submitted that the JSE and the FSB should be statutorily empowered to have more discretionary powers to combat and discourage all the types of market manipulation activities in South Africa.

${ }^{228}$ See ss 6 A to 6l; read with s 99 of the Financial Markets Act.

${ }^{229}$ Such compensatory money is only available in matters involving insider trading, see s 82 read with ss 80 \& 81 of the Financial Markets Act. This may indicate that the EC, unlike the SEC and the CFTC, does not have express statutory authority to make its own appropriate additional administrative remedies for market manipulation.

${ }^{230}$ See the FSB (28-06-2011) <http://www.fsb.co.za/ftp://ftp.fsb.co.za/public/documents/AReport2011.pdf> (accessed 22-11-2013); also see the FSB Annual Report 2011 101-102; Van Deventer 2009 FSB Bulletin 4 \& related discussion in paragraph 2.5 above.

231 See ss 80 \& 81 read with ss 109(a) \& 82 of the Financial Markets Act. Moreover, the Consumer Protection Act 68 of 2008, hereinafter referred to as the the Consumer Protection Act, also does not expressly provide for any private of action for the persons affected by market manipulation. See generally ss 115 \& 116 read with Part $C$ of the Consumer Protection Act. It is accordingly submitted that a private right of action provision should be enacted to give equal opportunity to all the affected persons to claim their own damages straight from the perpetrators of market abuse practices in South Africa.

${ }^{232}$ Generally see the sub-paragraphs under paragraph 2 above.

${ }^{233}$ See related discussion in the sub-paragraphs under paragraph 2 above.

${ }^{234}$ Generally see the sub-paragraphs under paragraph 2 above.

235 See the discussion in the sub-paragraphs under paragraph 2 above.

236 See ss 78; 80; 81; 82 read with ss 79 \&109(a).

${ }^{237}$ See related remarks in paragraphs $2.2 \& 2.5$ above.
} 
damages, bounty rewards, class actions and private rights of action are not expressly provided under the Financial Markets Act. 238

Given this background, it is submitted that the Financial Markets Act should be reviewed to enact specific provisions for separate and distinct criminal penalties that can be imposed upon any juristic person ${ }^{239}$ or individual who commit or attempts to commit market abuse offences in South Africa for deterrence purposes. Additionally, the Financial Markets Act should be amended to enact adequate provisions that prohibit Internet-based market abuse practices in South Africa. The Financial Markets Act should also be reviewed to enact provisions that expressly prohibit a person who inadvertently aided or abetted another person to commit market abuse practices from making or publishing a false, misleading or deceptive statement, promise or forecast that relates to any security in South Africa. It is also recommended that the Financial Markets Act should be reviewed to enact provisions that expressly prohibit commoditybased market manipulation and provide civil penalties for all market manipulation offences in South Africa.

\section{References}

Books

Arshadi N \& Eyssell TH The Law and Finance of Corporate Insider Trading: Theory and Evidence (Kluwer Academic Publishers Massachusetts 1993)

Avgouleas E The Mechanics and Regulation of Market Abuse: A legal and Economic Analysis (Oxford University Press Oxford 2005)

Barnes P Stock Market Efficiency, Insider Dealing and Market Abuse (Gower Publishing Limited Surrey England 2009)

Beuthin RC and Luiz SM Beuthin's Basic Company Law $3^{\text {rd }}$ ed (Butterworths Durban 2000)

Gaillard E (ed) Insider Trading: The Laws of Europe, the United States and Japan (Kluwer Law \& Taxation Publishers Deventer Netherlands 1992)

Hazen TL The Law of Securities Regulation: Handbook Series Student Edition (West Publishing Company St Paul, MN 1985)

Hazen TL Federal Securities Law $2^{\text {nd }}$ ed (Federal Judicial Center United States of America 2003)

Lyon GJ \& Du Plessis JJ The Law of Insider Trading in Australia (The Federation Press Sydney 2005)

Palmiter AR Securities Regulation: Examples and Explanations $3^{\text {rd }}$ ed (Aspen Publishers New York 2005)

Swan EJ Market Abuse Regulation $1^{\text {st }}$ ed (Oxford University Press United States of America 2006)

\section{Journal articles}

Bhattacharya U \& Daouk H "The World Price of Insider Trading" 2002 Journal of Finance 75-108

Botha D "Control of Insider Trading in South Africa: A Comparative Analysis" 1991 SA Merc LJ 1-18

Botha D "Increased Maximum Fine for Insider Trading: A Realistic and Effective Deterrent?" 1990 SALJ 504-508

Cassim R "An Analysis of Market Manipulation under the Securities Services Act 36 of 2004 (Part 1)" 2008 SA Merc LJ 33-60

Cassim R "An Analysis of Market Manipulation under the Securities Services Act 36 of 2004 (Part 2)" 2008 SA Merc LJ 177-199

Fisher J, Harshman E, Gillespie W, Ordower H, Ware L \& Yeager F "Privatizing Regulation: Whistle-blowing and Bounty Hunting in the

Financial Services Industries" 2000 Dick.J. Int'L. L 117-143

Friedman HM "The Insider Trading and Securities Fraud Enforcement Act of 1988" 1990 North Carolina Law Review 465-494

Gilson RJ \& Kraakman RH "The Mechanisms of Market Efficiency" 1984 VA.L.REV 549-644

Horwich A "The Origin, Application, Validity and Potential Misuse of Rule 10b5-1" 2007 The Bus. Lawyer 913-954

Jooste R "A critique of the insider trading provisions of the 2004 Securities Services Act" 2006 SALJ 437-460

Kaswell SJ "An Insider's View of the Insider Trading and Securities Fraud Enforcement Act" 1989 Bus.Law 145-180

Knepper ZT "Examining the Merits of Dual Regulation for Single-Stock Futures: How the Divergent Insider Trading Regimes for Federal

Futures and Securities Markets Demonstrate the Necessity for (and Virtual Inevitability of) Dual CFTC-SEC Regulation for Single-

Stock Futures" 2004 Pierce Law Review 33-47

Luiz SM “Insider Trading Regulation - If at First You Don't Succeed..." 1999 SA Merc LJ 136-151

Markham JW "'Front-Running'-Insider Trading under the Commodity Exchange Act" 1988 Cath.U.Review 69-127

Mossos E "Sarbanes-Oxley goes to Europe: A Comparative Analysis of United States and European Union Corporate Reforms after Enron" 2004 Currents International Trade Law Journal 9-22

Nelemans M "Redefining Trade-Based Market Manipulation" 2008 Valparaiso University Law Review 1169-1220

Osode PC "The new South African Insider Trading Act: Sound law reform or legislative overkill?" 2000 Journal of African Law 239-263

Pearce BD "Broadening Actual Damages in the Context of the Commodities Exchange Act" 2007 Journal of Law and Policy $449-483$

Pearson TC "When Hedge Funds Betray A Creditor Committee's Fiduciary Role: New Twists on Insider Trading in the International Financial Markets" 2009 Review of Banking \& Financial Law 165-220

Ryan L "Rule14e-3's Disclose or Abstain Rule and Its Validity under Section 14(e)" 1991 U. Cin. Law Review 449-465

Steinberg MI "Insider Trading Regulation-A Comparative Perspective" 2003 The International Lawyer 153-171

238 See s 82; also see related remarks in paragraphs 2.3 \& 2.6 above.

${ }^{239}$ It is submitted that a minimum fine of R750 million, or a much higher penalty should be imposed on juristic persons to increase deterrence and/or compliance with the market abuse prohibition in South Africa. 
Van Deventer G "New watchdog for insider trading" 1999 FSB Bulletin 2-3

Van Deventer G "Harnassing Administrative Law in Encouraging Compliance" 2009 FSB Bulletin 3-4

Case law

South Africa

Pretorius and Another v Natal South Sea Investment Trust 19653 SA 410 (W)

United States of America

Blue Chip Stamps v Manor Drug Stores (1975) 421 US 723

Cady, Roberts and Company [1961-1964 Transfer Binder] CCH Fed Sec L Rep 76. 803

Cargil Inc v Hardin case (1971) 452 F2d 1154

Central Bank of Denver NA v First Interstate Bank of Denver NA (1994) 511 US 164 (US SC)

Chiarella v United States (1980) 445 US 222

Comm 'n v Heffernan (2003) 274 FSupp2d 1375 (SDGa)

Dirks v SEC (1983) 463 US 646

Elkind $v$ Liggett and Myers Inc (1980) 635 F2d 156(2d Cir)

FMC Corp v Boesky (1988) $852 \mathrm{~F} 2 \mathrm{~d} 981$ (7th $\mathrm{Cir})$

FMC Corp v Boesky (1987) 673 F2d 272 (ND I11)

Godwin v Agassiz (1933) 186 NE 659 (Mass)

SEC v Boesky (1986) 86 Civ 8767

SEC v Levine (1986) 86 Civ 3726 (SDNY) (RO)

SEC v Lipson (2001) No 97-CV-2661 129F Supp.2d 1148

SEC v Sloan (1978) 436 US 103

SEC v Texas Gulf Sulphur Company (1968) 401 F2d 833 (2d Cir)

SEC v WorldCom Inc (2003) 02 Civ 4963(JSR)

SEC $v$ Yun (2003) $327 \mathrm{F3d} 1263\left(11^{\text {th }} \mathrm{Cir}\right)$

WHX Corp v SEC (2004) 362 F3d 854 (DC Cir)

United States v Chestman (1991) 947 F2d 551 (2d Cir)

United States v Falcone [2001 Transfer Binder] 91489 Fed Sec L Rep CCH (2d Cir)

United States v O'Hagan (1997) 117 (SCt) 2199

\section{Legislation \\ South Africa}

Companies Act 61 of 1973

Companies Act 71 of 2008

Consumer Protection Act 68 of 2008

Financial Markets Act 19 of 2012

Financial Institutions (Protection of Funds) Act 28 of 2001

Securities Services Act 36 of 2004

\section{United States of America}

Commodity Exchange Act of 19367 USC 1 et seq. (1994)

Commodities Futures Modernization Act 2000 Public Law 106-554, 114 Stat.2763A-365

Commodity Futures Trading Commission Act of 1974 Public Law 93-64, 88 Stat 1398

Derivatives Market Manipulation Prevention Act of 2009

Dodd-Frank Wall Street Reform and Consumer Protection Act of 2010, Public Law 111-203, 124 Stat.1376 (12 USC; s 5301 et seq.)

Insider Trading and Securities Fraud Enforcement Act of 1988 Public Law 100-704, 102 Stat 4677

Insider Trading Sanctions Act of 1984 Public Law 98-376, 98 Stat.1264 (1984)

International Securities Enforcement Cooperation Act of 1990

Investment Advisors Act of 1940

Investment Company Act of 1940

Public Company Accounting Reform and Investor Protection Act of 2002 Public Law 107-204, 116 Stat 745 (15; 28 USC)

Public Utility Holding Company Act of 1935

Racketeer Influenced and Corrupt Organization Act of 1970

Securities Act of 1933 Public Law 2248 Stat 7415 USC77a-77mm (1994)

Securities Act of 1933, Public Law 2248 Stat.74 15 USC 77a-77mm et seq. (2000)

Securities Act of 193315 USC 77q(a) (2006) as amended by PL-111-229 (approved 11-08-2010)

Securities Exchange Act of 1934 Public Law 73-291, 48 Stat 88115 USC 78a-78II

Securities Exchange Act of 193415 USC 78i(a)(2)-(5) (2006) as amended by PL-111-257 (approved 05-10-2010)

Securities Exchange Act Release Number 43154 [2000 Transfer Binder] Fed Sec L Rep CCH 86.319 
Trust Indenture Act of 1939

Commissions, committees and reports

South Africa

Financial Services Board Annual Report 2011

Financial Services Board Annual Report 2013

The King Task Group into Insider Trading Legislation Minority Report on Insider Trading 1997

The King Task Group into the Insider Trading Legislation First Report 15 May 1997

The King Task Group into the Insider Trading Legislation Final Report 21 October 1997

Van Wyk de Vries Commission of Inquiry into the Companies Act of 1973

United States of America

The Commodity Futures Trading Commission \& the United States Securities and Exchange Commission "A Joint Report of the SEC and the CFTC on Harmonization of Regulation" Report 16 October 2009

Thesis and dissertations

Chitimira H A Comparative Analysis of the Enforcement of Market Abuse Provisions (LLD-thesis Nelson Mandela Metropolitan University 2012)

Chitimira H The Regulation of Insider Trading in South Africa: A Roadmap for an Effective, Competitive and Adequate Regulatory Statutory Framework (LLM-dissertation University of Fort Hare 2008)

Conference papers, media releases and other relevant material

Morrison \& Foerster "Insider Trading" 2010 Year End Review 1

The United States Department of Justice District of Delaware "Newark Man Pleads Guilty to Insider Trading Charges" Press Release 25 March 2011

Newspaper reports

Chanetsa B "Insider Trading is Notoriously Hard to Prosecute" Business Report 26 April 2004

Internet sources

Cantwell M "Senate Passes Cantwell Anti-Manipulation Amendment" (06-05-2010) <http://cantwell.senate.gov/news/record.cfm ?id=324761> (accessed 26-11-2013)

Financial Services Board "Enforcement Committee Actions" Media Release (28-06-2011) <http://www.fsb.co.za/ftp://ftp.fsb.co.za /public/documents/AReport2011.pdf> (accessed 22-11-2013)

Financial Services Board "List of Current Investigations of the Directorate of Market Abuse" Media Release (28-06-2011) $<$ http://www.fsb.co.za/ftp://ftp.fsb.co.za/public/documents/AReport2011.pdf> (accessed 22-11-2013)

Morgan Lewis "2009 Year in Review: SEC and SRO Selected Enforcement Cases and Developments Regarding Broker-Dealers" 2010 $<$ http://www.morganlewis.com/lit_SECandYearlyReviewWP_Jan2010.pdf> (accessed 10-06-2013)

Myburgh A \& Davis B "The Impact of South Africa's Insider Trading Regime: A Report for the Financial Services Board" (25-03-2004) $<$ http://www.genesis-analytics.com/public/FSBReport.pdf> (accessed 09-02-2013)

Van Deventer G "Anti-Market Abuse Legislation in South Africa" (10-06-2008) <http://www.fsb.co.za/public/marketabuse/FSBReport.pdf> (accessed 05-05-2013) 